\title{
ANALISIS VISUALISASI DAN PEMETAAN DATA TANAMAN PADI DI INDONESIA MENGGUNAKAN MICROSOFT POWER BI
}

\author{
Ridho Darman \\ Program Studi Sistem Informasi, Fakultas Teknologi Informasi Universitas Andalas \\ Jl. Universitas Andalas, Limau Manis, Pauh, Limau Manis, Pauh, Kota Padang, Sumatera Barat 25163. \\ Email: ridhodarman@gmail.com
}

\begin{abstract}
ABSTRAK
Tanaman padi merupakan tanaman yang paling penting karena merupakan sumber makanan pokok masyarakat Indonesia. Pertumbuhan penduduk di Indonesia dan diikuti dengan tingkat produksi padi yang tidak merata tentu menjadi masalah serius bagi Indonesia dalam mencukupi kebutuhan pangan nasional. Informasi kebijakan pemerintah dalam pengembangan komoditas padi sangatlah penting karena komoditas ini memiliki peran penting dalam menjaga stabilitas kebutuhan pangan nasional. Badan Pusat Statistik adalah lembaga yang memiliki berbagai data sensus dan survei dalam ukuran yang sangat besar. Agar data tersebut dapat diolah menjadi informasi yang lebih bernilai dibutuhkan sebuah aplikasi business intelligence yang dapat memvisualisasikan data-data tersebut sehingga dapat menampilkan informasi daerah dengan produksi dan produktivitas padi yang tinggi maupun yang rendah. Pengelompokan data ini bertujuan untuk mempermudah pengguna dalam mendapatkan informasi mengenai produksi dan produktivitas tanaman padi di setiap daerah di Indonesia sehingga dapat menjadi acuan bagi Kementerian Pertanian dalam perumusan dan penetapan kebijakan di bidang penyediaan prasarana dan sarana pertanian, peningkatan produksi padi dan pertanian lainnya. Pada penelitian ini digunakan salah satu business intelligence software untuk dapat mengelompokkan data tanaman padi serta visualisasinya dalam bentuk informasi grafik dan peta kartogram area dengan metode Online Analytical Processing (OLAP).
\end{abstract}

Kata Kunci: business intelligence, Microsoft Power BI, padi, pemetaan, visualisasi.

\section{A. PENDAHULUAN}

Badan Pusat Statistik adalah Lembaga Pemerintah Non Kementerian yang sebelumnya, bernama Biro Pusat Statistik. Biro Pusat Statistik dibentuk berdasarkan UU No. 6 Tahun 1960 tentang Sensus dan UU No. 7 Tahun 1960 tentang Statistik. Sebagai pengganti kedua UU tersebut maka ditetapkanlah UU Nomor 16 Tahun 1997 tentang Statistik. Berdasarkan UU ini dan dilengkapi dengan peraturan perundangan dibawahnya, secara formal nama Biro Pusat Statistik berubah menjadi Badan Pusat Statistik [1]. Peran BPS menurut UU No. 16 Tahun 1997 adalah menyediakan kebutuhan data bagi pemerintah dan masyarakat. Data tersebut didapatkan melalui sensus atau survei yang dilakukan sendiri dan juga berasal dari departemen atau lembaga pemerintahan lainnya sebagai data sekunder [2]. BPS memiliki berbagai macam data sensus dan survei termasuk data tanaman padi perprovinsi di Indonesia.

Indonesia adalah negara agraris yang didominasi oleh kegiatan di sektor pertanian [3]. Jumlah penduduk Indonesia saat ini kurang lebih sebanyak 228 juta jiwa, dengan pertumbuhan penduduk mencapai 1,64 \% dan Total Fertility Rate (TFR) sebesar 2,6. Dilihat dari segi kuantitas, jumlah penduduk Indonesia terbilang cukup besar [4]. Penduduk Indonesia mayoritas penduduk mengonsumsi nasi sebagai makanan pokok [5]. Nasi merupakan beras yang telah dimasak, dimana beras berasal dari tanaman padi. Luas daratan Negara Indonesia kurang lebih 190,9 juta hektar. dimana $37,1 \%$ telah digunakan untuk kegiatan budidaya seperti sawah, pertanian dengan lahan kering, perkebunan, ladang dan penggunaan lainnya, sedangkan 62,9\% lainnya berupa hutan. Pertumbuhan angka jumlah penduduk yang terus meningkat, diikuti dengan pertumbuhan ekonomi dan industri, menimbulkan konversi lahan pertanian. Konversi lahan adalah perubahan fungsi sebagian atau seluruh kawasan lahan dari fungsi semula menjadi fungsi yang lain [6]. Pertanian memiliki peranan penting dalam sektor perekonomian di Indonesia, karena sebagian besar kebutuhan pokok rakyat berasal dari sektor pertanian [7].

Banyaknya data survei dan sensus khususnya tanaman padi yang terdapat pada BPS harus terorganisir dan sistematis sehingga mempermudah dalam pengambilan keputusan, misalnya pengelompokkan daerah dengan produktivitas padi paling rendah di Indonesia. Pengelompokkan bertujuan agar masyarakat dan BNPB khususnya dapat mengetahui provinsi mana saja yang paling banyak produksi padinya dan provinsi mana yang paling sedikit produksi padinya. Hal ini agar dapat menjadi acuan bagi Kementerian Pertanian dalam perumusan dan penetapan kebijakan di bidang penyediaan prasarana dan sarana pertanian, peningkatan produksi padi dan pertanian lainnya, 
serta peningkatan nilai tambah, daya saing, mutu, dan pemasaran hasil pertanian sesuai dengan Peraturan Presiden No. 45 tahun 2015 Tentang Kementerian Pertanian, sehingga dapat meningkatkan kesejahteraan masyarakat Indonesia dalam memenuhi kebutuhan pokok. Ketersediaan pangan yang stabil merupakan salah satu kebutuhan dalam kelangsungan sebuah negara untuk mencukupi kebutuhan pangan nasional. Informasi kebijakan pemerintah dalam pengembangan komoditas padi yang dilakukan sangat penting karena komoditas ini memiliki peran penting dalam menjaga stabilitas kebutuhan pangan nasional [8]. Supaya data BPS dapat dimanfaatkan dengan baik, dibutuhkan aplikasi business intelligence yang dapat menampilkan hasil visualisasi dan pemetaan agar dapat mempermudah pihak yang berkepentingan dalam mengolahnya untuk keperluan pengambilan keputusan.

Penelitian ini menggunakan salah satu aplikasi business intelligence yang dapat membantu BPS dalam mengoordinir data yang dimilikinya. Microsoft Power BI merupakan aplikasi business intelligence yang digunakan untuk dapat menampilkan informasi seperti mengelompokkan provinsi di Indonesia yang memiliki tingkat produktivitas tanaman padi yang tinggi ataupun yang rendah berdasarkan data yang diperoleh dari BPS. Microsoft Power BI juga memiliki fitur digital mapping (pemetaan digital) sehingga dapat menampilkan peta persebaran produksi tanaman padi di Indonesia.

\section{B. LANDASAN TEORI \\ B.1. Tanaman Padi}

Tanaman padi (Oryza sativa L.) merupakan tanaman semusim dengan morfologi berbatang bulat dan berongga yang disebut sebagai jerami. Bentuk daunnya memanjang dengan ruas searah batang daun [9]. Padi adalah salah satu tanaman budidaya terpenting dalam peradaban juga tanaman yang paling penting di Indonesia karena makanan pokok di Indonesia adalah nasi. Nasi berasal dari beras yang dihasilkan oleh tanaman padi [10]. Tanaman padi termasuk ke dalam tanaman air (waterplant). Meskipun tergolong ke dalam tanaman air bukan berarti bahwa tanaman padi hanya dapat tumbuh di atas tanah yang terus menerus digenangi oleh air, tanaman padi bisa tumbuh ditanah daratan atau tanah yang kering, asalkan curahan hujannya mencukupi akan kebutuhan tanaman air tersebut. Masyarakat Indonesia mengonsumsi padi yang telah digiling kulitnya (beras) kemudian dimasak menjadi nasi sebagai sumber energi. Nasi banyak mengandung karbohidrat yang berguna sebagai bahan bakar bagi tubuh dan membantu dalam menjalankan fungsi normal otak [10].

\section{B.1.1. Produksi Padi}

Produksi padi merupakan salah satu hasil bercocok tanam yang dilakukan dengan penanaman bibit padi, perawatan dan pemupukan secara teratur sehingga mampu menghasilkan suatu produksi padi yang dapat dimanfaatkan [11]. Data hasil produksi padi yang dimiliki oleh BPS adalah dalam satuan ton pertahun di setiap provinsi di Indonesia.

\section{B.1.2. Produktivitas Padi}

Produktivitas padi adalah produksi padi persatuan luas lahan yang digunakan dalam melakukan usaha bertani padi [12]. Produktivitas padi ditampilkan dalam persamaan berikut:

$$
\text { Produktivitas }=\frac{\text { Jumlah Produksi }}{\text { Luas Lahan }}
$$

\section{B.2. Visualisasi}

Visualisasi adalah rekayasa dalam pembuatan gambar, diagram atau animasi untuk penampilan suatu informasi [13]. Teknik visualisasi informasi dapat membantu masalah eksplorasi data set yang besar [14]. Terdapat dua konsep visualisasi, yaitu scientific visualisation dan information visualisation, kedua konsep tersebut membuat model grafis dan menampilkan data secara visual yang berinteraksi langsung dengan pengguna. Dalam memperoleh informasi dan melakukan eksplorisasi data pada scientific visualisation, umumnya model grafis dibangun dari pengukuran atau simulasi data yang mewakili objek atau konsep yang terkait dengan fenomena yang sebenarnya. Pada information visualisation konsep abstrak dan hubungan tidak selalu memiliki keterkaitan di dunia nyata [15]. Tujuan utama dari visualisasi data adalah untuk mengomunikasikan informasi secara jelas dan efisien kepada pengguna lewat bentuk grafik informasi yang dipilih. Grafik adalah gambaran pasang surutnya suatu kondisi atau data yang ada dengan garis ataupun gambar [16].

\section{B.3. Pemetaan}

Menurut Kamus Besar Bahasa Indonesia (KBBI), pemetaan adalah proses, cara, perbuatan membuat peta. Peta adalah gambar atau lukisan pada kertas dan sebagainya yang menunjukkan letak tanah, laut, sungai, gunung, dan sebagainya; representasi melalui gambar dari suatu daerah yang menyatakan sifat, seperti batas daerah, sifat permukaan; denah [17]. Perkembangan peta tematik meningkat cukup pesat. Metode pembuatan ataupun transformasi bentuk peta tematik itu sendiri memiliki berbagai macam jenis sebagai upaya untuk meningkatkan efektivitas peta di dalam memvisualisasikan data statistik. Salah satu cara untuk visualisasi data tematik dengan cara dipetakan adalah dengan menggunakan kartogram. Kartogram merupakan bentuk dari peta tematik yang bersifat unik, karena kartogram merupakan 
peta tematik yang masuk dalam ketegori graphic manipulation. Terdapat 2 jenis kartogram, yaitu kartogram linier dan kartogram area. Perbedaan jenis kartogram tersebut dibedakan atas dimensi kenampakan yang divisualisasikan. Pada kartogram linier menggunakan dimensi kenampakan garis, sedangkan kartogram area menggunakan dimensi kenampakan area [18].

\section{B.4. Microsoft Power BI}

Microsoft Power BI merupakan salah satu business intelligent software atau seperangkat alat business analytics yang dapat meningkatkan wawasan terhadap instansi atau organisasi. Micrsoft Power BI dapat terhubung hingga ratusan sumber data, menyederhanakan persiapan data, dan menggerakkan analisis adhoc. Laporan yang dihasilkan dapat ditampilkan di web maupun perangkat mobile serta mampu membuat dashboard yang dipersonalisasi dengan tampilan 360 derajat [19]. Ada berbagai macam bentuk visualisasi grafik yang dapat digunakan di Microsoft Power BI diantaranya stacked bar chart, stacked column chart, clustered bar chart, clustered column chart, line chart, area chart, stacked area chart, ribbon chart, pie chart, donut chart, treemap, dan yang lainnya. Microsoft Power BI terintegrasi dengan Bing Maps untuk menyediakan koordinat peta default (sebuah proses yang disebut geo-coding) sehingga dapat membuat tampilan peta dilengkapi dengan algoritma untuk mengidentifikasi lokasi yang benar. Microsoft Power BI dapat memastikan bidang geografis berdasarkan field yang telah diberi geo-code dengan menetapkan data category pada data fields, dengan cara: pilih tabel yang diinginkan, lalu pergi ke Advanced Ribbon dan set data category-nya ke alamat, kota, benua, negara, kode pos, negara bagian atau provinsi. Kategori-kategori akan membantu bing dalam encode the date dengan benar [20].

\section{B.5. Business Intelligence}

Menurut Kimball dan Caserta, Business Intelligence (BI) merupakan suatu proses ekstraksi data operasional organisasi atau perusahaan, lalu dikumpulkan ke dalam sebuah data warehouse. Data warehouse dirancang untuk mendukung sebuah proses lanjutan untuk mendapatkan informasi berharga dengan menggunakan teknik data mining. Hasil analisis data yang diperoleh berupa kunci-kunci pengetahuan bisnis yang bermanfaat dalam peningkatan kinerja organisasi. Visualisasi dari BI dapat disajikan dalam bentuk dashboard untuk mendapatkan informasi detail. Tampilan visualisasi di dalam dashboard bisa berupa grafik, pie, custom, drill down dan lain sebagainya. Dashboard berfungsi sebagai pemantau untuk mewujudkan strategi yang tepat dan berkualitas bagi top level manajemen khususnya yang terkait dengan pengambilan keputusan [21].

\section{METODOLOGI PENELITIAN}

Metode yang digunakan dalam penelitian ini adalah Online Analytical Processing (OLAP). OLAP merupakan suatu jenis pemrosesan yang dapat memanipulasi dan menganalisa data yang memiliki volume dalam ukuran besar dari berbagai perspektif (multidimensi). OLAP dapat membantu user dalam menganalisis data yang terdapat pada sebuah data warehouse dengan berbagai tampilan visualisasi data, dan representasi grafik yang dinamis [22]. Penggunaan metode OLAP dan Microsoft Power BI sebagai business intelligence software diharapkan akan mampu mempermudah pengguna dalam menampilkan hasil visualisasi dan pemetaan yang dapat digunakan untuk keperluan pengambilan keputusan.

\section{PEMBAHASAN DAN HASIL}

Pada bab ini akan diuraikaan mengenai pembahasan dan hasil penelitian, yaitu bagaimana hasil dari pengolahan data-data tanaman padi di Indonesia ada sehingga didapatkan output berupa tampilan visualisasi dan pemetaan tanaman padi di Indonesia serta analisisnya.

\section{D.1. Pengumpulan Data}

Data yang digunakan adalah data tanaman pangan padi perprovinsi dari tahun 1993-2013 yang diperoleh dari BPS. Data yang diperoleh dalam bentuk format excel sebanyak 694 baris data, kemudian data tersebut disesuaikan agar dapat di import ke database dan dianalisa menggunakan Microsoft Power BI. Microsoft Power BI dapat digunakan secara open source dan tersedia dalam versi web yang dapat diakses melalui app.powerbi.com.

\section{D.2. Implementasi Pada Microsoft Power BI}

Setelah proses import data berhasil dilakukan, kemudian dilakukan pengolahan data menggunakan Microsoft Power BI. Langkah-langkah yang dilakukan untuk melakukan pengolahan data pada Microsoft Power BI adalah sebagai berikut:

(1) buka himpunan data my workspace, kemudian pilih data yang sudah di-import tadi;

(2) pilih jenis tampilan grafik yang ingin ditampilkan;

(3) tentukan field yang akam menjadi sumber nilai untuk nilai axis dan value-nya;

(4) atur tamplian informasi yang diinginkan berdasarkan kebutuhan, misalnya filter nilai 10 teratas atau terbawah, tapilkan, tampilkan niali rata-rata atau jumlah, dan sebagainya;

(5) membuat tampilan dashboard berdasarkan tampilan informasi yang diinginkan. 
Bentuk tampilan dashboard yang dibangun pada penelitian ini terdiri dari dua halaman. Dasboard halaman pertama dapat dilihat pada Gambar 1.



Gambar 1. Tampilan dashboard halaman pertama

Pada dashboard halaman pertama, ditampilkan informasi mengenai rata-rata jumlah produksi padi di Indonesia pada tahun 1993-2013 di setiap provinsi. Peta persebaran produksi tanaman padi di Indonesia dari tahun 1993-2013 dapat dilihat pada Gambar 2.

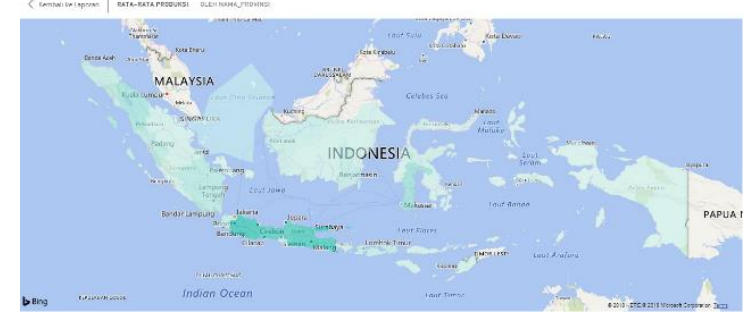

Gambar 2. Peta persebaran produksi tanaman padi

Pada Gambar 2, peta persebaran produksi tanaman padi di setiap provinsi di Indonesia ditampilkan dalam peta tematik berupa katogram area, dimana disetiap area (provinsi) diwakili oleh rata-rata jumlah produksi tanaman padinya masingmasing. Semakin gelap warna hijau yang terdapat pada peta, maka semakin tinggi nilai rata-rata jumlah produksinya. Dari tampilan peta pesebaran produksi tanaman padi tersebut dapat kita lihat sejumlah provinsi yang terdapat di Pulau Jawa merupakan provinsi dengan nilai rata-rata produksi tanaman padi yang tertinggi di Indonesia, selebihnya produksi tanaman padi juga dihasilkan di Provinsi Sulawesi Selatan dan beberapa provinsi di Pulau Sumatera dan dengan jumlah yang lebih sedikit dibandingkan beberapa provinsi di Pulau Jawa. Tampilan 10 provinsi dengan nilai rata-rata produksi tanaman padi tertinggi di Indonesia pada tahun 1993-2013 dapat dilihat pada Gambar 3.

Pada Gambar 3, dapat dilihat provinsi Jawa Barat merupakan provinsi dengan nilai rata-rata produksi tanaman padi tertinggi di Indonesia dari tahun 1993 sampai 2013, dengan nilai rata-rata produksi mencapai lebih dari 10 juta ton pertahunnya. Pada 10 provinsi dengan nilai ratarata produksi tertinggi juga terdapat secara berurutan 2 provinsi di Pulau Jawa, yaitu Jawa Timur dan Jawa Tengah. Lalu Provinsi Sulawesi Selatan, 4 provinsi di Pulau Sumatera yaitu Sumatera Utara, Sumatera Selatan, Lampung, dan Sumatera Barat. Kemudian juga di Provinsi Kalimantan Selatan dan Nusa Tenggara Barat. Untuk melihat 10 provinsi dengan nilai rata-rata produksi paling rendah dapat ditampilkan melalui grafik seperti pada Gambar 4.

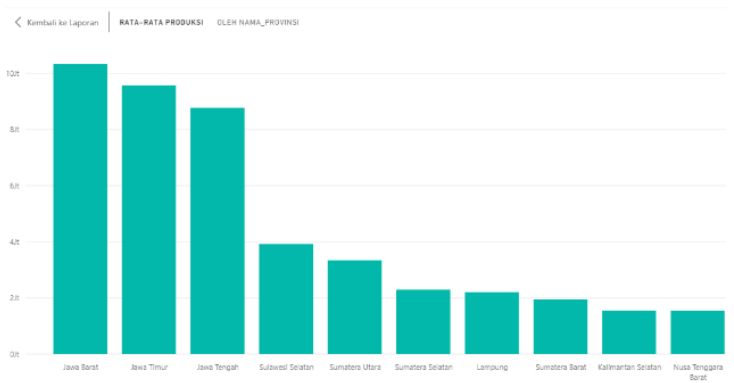

Gambar 3. Sepuluh provinsi dengan nilai rata-rata produksi tanaman padi tertinggi

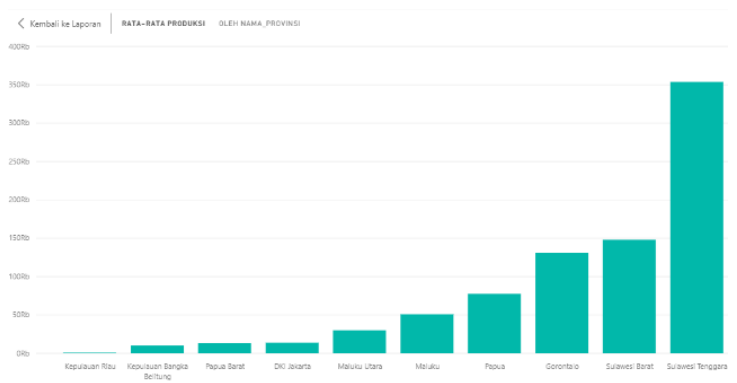

Gambar 4. Sepuluh provinsi dengan nilai rata-rata produksi tanaman padi terendah

Pada Gambar 4, dapat dilihat Provinsi Kepulauan Riau merupakan provinsi dengan nilai rata-rata produksi tanaman padi terendah di Indonesia dari tahun 1993 sampai dengan 2013 dengan nilai rata-rata produksi kurang dari 0,05 juta ton per tahunnya, diikuti dengan 9 provinsi lainnya secara berurutan yaitu Provinsi Kepulauan Bangka Belitung, Papua Barat, D.K.I. Jakarta, Maluku Utara, Maluku, Papua, Gorontalo, Sulawesi Barat, dan Sulawesi Tenggara. Sedangkan 10 provinsi dengan nilai rata-rata luas panen tanaman tertinggi ditampilkan seperti Gambar 5.

Pada Gambar 5, dapat dilihat Provinsi Jawa Barat merupakan provinsi dengan nilai rata-rata luas panen tertinggi dari tahun 1993 sampai 2013 dengan nilai rata-rata lebih dari 1,97 juta hektar (Ha), lalu secara berurutan diikuti dengan Provinsi Jawa Timur, Jawa Tengah, Sulawesi Selatan, Sumatera Utara, Sumatera Selatan, Lampung, Kalimantan Selatan, Sumatera Barat, dan Kalimantan Barat. Kemudian 10 provinsi dengan nilai rata-rata produktivitas tanaman padi tertinggi ditampilkan seperti Gambar 6. 


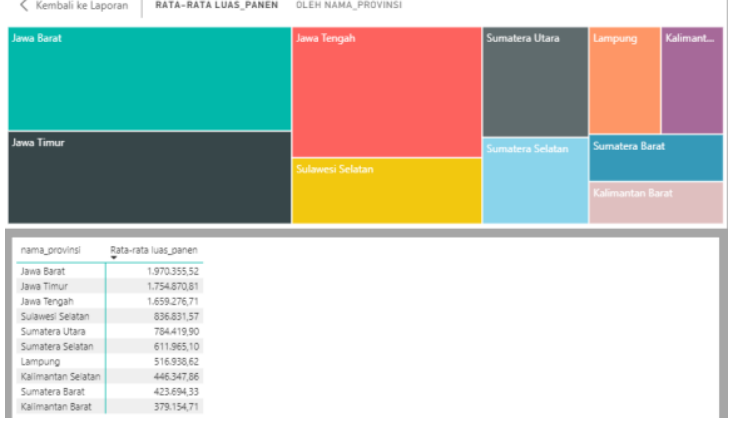

Gambar 5. Sepuluh provinsi dengan nilai rata-rata luas panen tanaman padi tertinggi

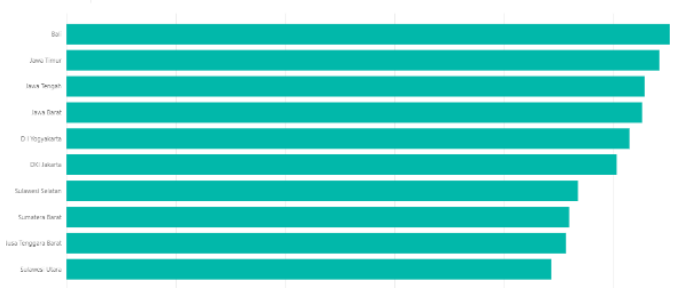

Gambar 6. Sepuluh provinsi dengan nilai rata-rata produktivitas tanaman padi tertinggi

Pada Gambar 6, dapat dilihat bahwa Provinsi Bali merupakan provinsi dengan nilai rata-rata produktivitas tanaman padi tertinggi dari tahun 1993 sampai 2013 dengan nilai rata-rata produktivitas lebih dai $55 \mathrm{Ku} / \mathrm{Ha}$, selanjutnya diikuti secara berurutan oleh Provinsi Jawa Timur, Jawa Tengah, Jawa Barat, D.I. Yogyakarta, D.K.I. Jakarta, Sulawesi Selatan, Sumatera Barat, Nusa Tenggara Barat, dan Sulawesi Utara. Sedangkan 10 provinsi dengan nilai rata-rata produktivitas tanaman padi terendah ditampilkan seperti Gambar 7.

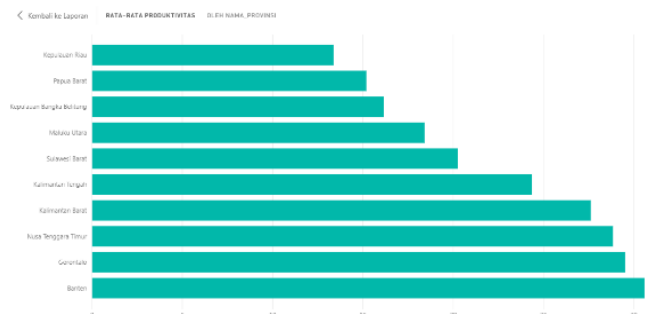

Gambar 7. Sepuluh provinsi dengan nilai rata-rata produktivitas tanaman padi terendah

Pada Gambar 7, dapat dilihat bahwa Provinsi Kepulauan Riau merupakan provinsi dengan produktivitas tanaman padi paling rendah yaitu kurang dari $15 \mathrm{Ku} / \mathrm{Ha}$ dari tahun 1993 sampai 2013. Selanjutnya provinsi dengan produktivitas tanaman padi terendah lainnya pada tahun 1993203 secara berurutan adalah Provinsi Papua Barat, Kepulauan Bangka Belitung, Maluku Utara, Sulawesi Barat, Kalimantan Tengah, Kalimantan Barat, Nusa Tenggara Timur, Gorontalo, dan Banten. Berikutnya visualisasi data pertahun dapat dilihat pada dashboard halaman kedua. Tampilan dashboard halaman kedua dapat dilihat pada Gambar 8 .

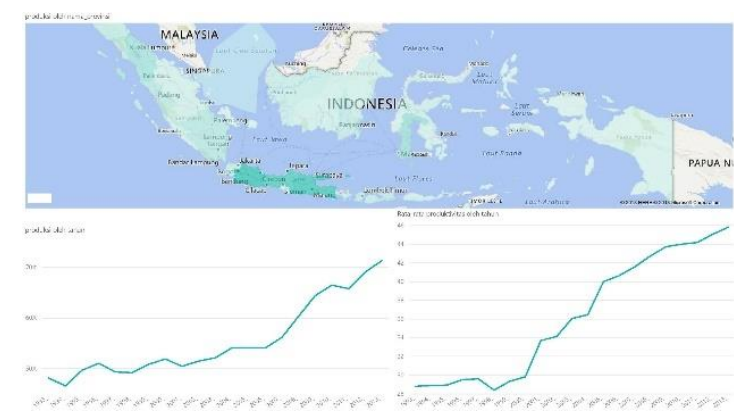

Gambar 8. Tampilan dashboard halaman kedua

Pada dashboard halaman kedua ditampilkan peta persebaran jumlah seluruh produksi tanaman padi yang pernah dihasilkan, jumlah produksi tanaman padi pertahun, dan rata-rata produktivitas tanaman padi pertahun dari tahum 1993 sampai dengan 2013. Peta jumlah produksi tanaman padi yang pernah dihasilkan selama tahun 1993 hingga 2013 dapat dilihat pada Gambar 9.

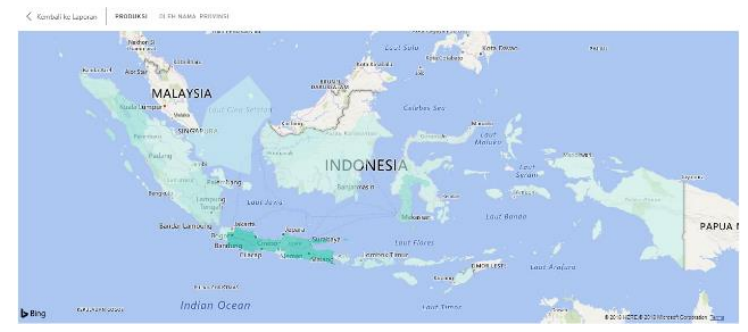

Gambar 9. Peta jumlah produksi tanaman padi selama 1993-2013

Pada Gamabar 9 dapat dilihat bahwa beberapa Provinsi di Pulau Jawa merupakan penyumbang produksi tanaman padi terbesar di Indonesia selama 20 tahun (1993-2013). Jumlah produksi tanaman padi di Indonesia pertahunnya ditampilkan seperti Gambar 10.

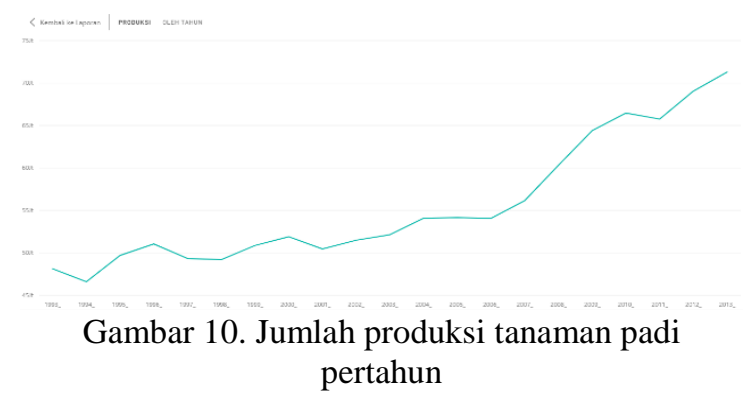

Pada Gambar 10, dapat dilihat produksi tanaman padi terendah terjadi pada tahun 1994. Produksi tanaman padi mengalami fluktuasi dari tahun 1993-2006. Pada tahun 2006-2010 produksi padi selalu mengalami peningkatan, sampai pada tahun 2011 mengalami penurunan, kemudian dari tahun 2011-2013 kembali mengalami peningkatan. Tingkat produksi tanaman padi di Indonesia paling 
tinggi terjadi pada tahun 2013 dengan total produksi mencapai lebih dari 70 juta ton. Rata-rata produktivitas tanaman padi di Indonesia per tahunnya dapat dilihat pada Gambar 11.



Pada Gambar 11, dapat dilihat produktivitas tanaman padi di Indonesia pada tahun 1993-2013 hanya mengalami satu kali penurunan, yaitu pada tahun 1998 sekaligus menjadi angka produktivitas tanaman padi terendah. Sedangkan angka produktivitas tanaman padi tertinggi terjadi pada tahun 2013 yaitu lebih dari $45 \mathrm{Ku} / \mathrm{Ha}$. Pada dashboard halaman kedua juga dapat menampilkan detail informasi perwilayah, masing-masing visualisasi dan grafik yang terdapat di dalamnya saling terhubung. Contoh, apabila ingin menampilkan informasi pada wilayah Provinsi Sumatera Barat dapat dilihat seperti pada Gambar 12.

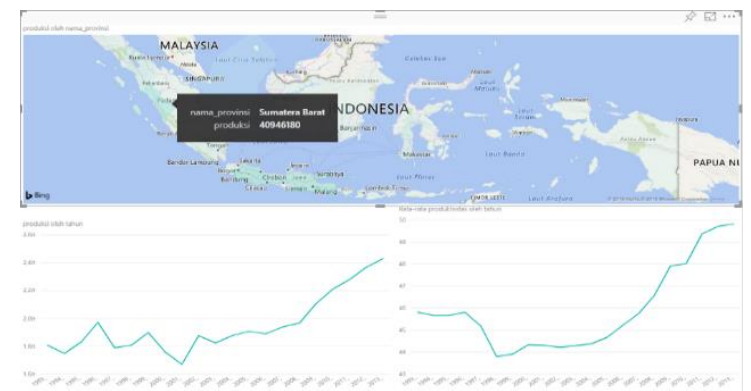

Gambar 12. Detail informasi tanaman padi di Provinsi Sumatera Barat

Pada saat kursor mouse diarahkan ke suatu wilayah, maka akan ditampilkan info window mengenai jumlah produksi tanaman padi pada wilayah tersebut. Pada Gambar 12, dapat dilihat jumlah produksi tanaman padi di Provinsi Sumatera Barat dari tahun 1993 sampai 2013 berjumlah 40,9 juta ton dengan jumlah produksi selalu berfluktuasi dari tahun 1993 sampai 2006. Dari tahun 2006 sampai 2013 produksi tanaman padi di Provinsi Sumatera Barat terus meningkat. Produksi tanaman padi tertinggi di Provinsi Sumatera Barat terjadi pada tahun 2013 sebanyak 2,4 juta ton dan paling sedikit terjadi pada tahun 2001 sebanyak 1,67 juta ton. Untuk angka produktivitas tanaman padi mengalami fluktuasi dari tahun 1993 sampai 2002. Sedangkan dari tahun 2002 sampai dengan 2013 selalu mengalami peningkatan. Angka produktivitas tanaman padi tertinggi di Provinsi
Sumatera Barat terjadi pada tahun 2013 dengan nilai produktivitas $49,82 \mathrm{Ku} / \mathrm{Ha}$ dan yang terendah terjadi pada tahun 1998 dengan nilai produktivitas $43,74 \mathrm{Ku} / \mathrm{Ha}$.

\section{D.3. Analisis Hasil}

Pada penelitian ini yang menggunakan Microsoft Power BI sebagai salah satu business intelligence software dalam memperoleh informasi mengenai data tanaman padi di Indonesia baik berupa visualisasi grafik-grafik, pemetaan maupun data-data yang diperlukan dapat dianalisis bahwa daerah dengan tingkat produksi padi tertinggi di Indonesia terdapat di beberapa provinsi di Pulau Jawa, Sumatera, dan provinsi lainnya. Sedangkan beberapa provinsi yang terletak di pulau yang lebih kecil atau kepulauan seperti Kepulauan Riau, Kepulauan Bangka Belitung, Maluku, dan Maluku Utara memiliki tingkat produksi tanaman padi yang rendah. Tingkat produksi tanaman padi yang rendah juga terjadi di daerah perkotaan yaitu D.K.I Jakarta dan di Pulau Papua.

\section{E. KESIMPULAN}

Indonesia merupakan negara agraris dimana kegiatan perekonomiannya bergantung pada sektor pertanian. Produksi padi di Indonesia terbilang cukup besar, namun jumlah penduduk Indonesia juga besar. Oleh karena itu diperlukan pemerataan produksi tanaman padi di Indonesia sesuai dengan kebutuhan penduduk di masing-masing wilayah agar dapat meningkatkan kesejahteraan Negara Indonesia terutama di bidang kebutuhan pokok dan pangan. Berdasarkan data tanaman padi di Indonesia selama 20 tahun, yaitu dari tahun 1993 sampai dengan 2013 dengan bantuan aplikasi Microsoft Power BI, maka dapat ditarik kesimpulan berupa: (1) Provinsi dengan tingkat nilai rata-rata produksi tanaman padi tertinggi pertahunnya di Indonesia adalah Jawa Barat, sedangkan nilai rata-rata produksi tanaman terendah pertahunnya berada di Kepulauan Riau; (2) Wilayah dengan angka rata-rata produktivitas tanaman padi tertinggi pertahunnya adalah Provinsi Bali, sedangkan angka rata-rata produktivitas terendah pertahunnya berada di Kepulauan Riau; (3) Jawa Barat merupakan provinsi dengan rata-rata luas panen terbesar pertahunnya; (4) Selama 20 tahun, Provinsi Jawa Barat merupakan provinsi yang paling banyak menghasilkan tanaman padi; (5) Produksi tanaman padi terbanyak terjadi pada tahun 2013 dengan total angka mencapai lebih dari 71 juta ton, sedangkan produksi tanaman padi paling sedikit terjadi pada tahun 1994 dengan produksi sebanyak 46,6 juta ton; (6) Jumlah produksi tanaman padi di Indonesia hampir mengalami fluktuasi setiap tahunnya; (7) Angka produktivitas tanaman padi di Indonesia paling tinggi terjadi pada tahun 2013 dengan nilai produktivitas $45,83 \mathrm{Ku} / \mathrm{Ha}$, sedangkan yang 
terendah terjadi pada tahun 1998 dengan nilai produktivitas $28,40 \mathrm{Ku} / \mathrm{Ha}$; dan (8) Sejak tahun 2000 hingga 2013 produktivitas tanaman padi di Indonesia terus mengalami peningkatan.

Microsoft Power BI sangat membantu dalam menampilkan informasi mengenali data tanaman padi tentang tingkat produksi dan produktivitas, sehingga pengguna bisa mengetahui daerah dengan tingkat produksi maupun produktivitas tanaman padi yang tinggi ataupun yang rendah berdasarkan data-data yang telah ada. Ini juga dapat menjadi acuan bagi Pemerintah Indonesia atau dalam hal ini merujuk kepada Kementerian Pertanian dalam perumusan dan penetapan kebijakan di bidang penyediaan prasarana dan sarana pertanian, peningkatan produksi padi dan pertanian lainnya sesuai dengan kebutuhan masyarakat dan kondisi alamnya.

\section{REFERENSI}

[1] [BPS] Badan Pusat Statistik, Tentang BPS. https://www.bps.go.id/menu/1/sejarah.html. Diakses pada tanggal 05 Juni 2018.

[2] Undang-Undang Republik Indonesia Nomor 16 Tahun 1997 Tentang Statistik.

[3] Harini R, Yunus HS, dan Hartono S. 2014. Analisis Spasial Sikap Petani Dalam Mempertahankan Tanah Pertanian Di Kabupaten Sleman, Indonesia. Geogr. Online Malaysia J. Soc. Sp., vol. 10, no. 2, pp. $154-167$.

[4] Kolifah, Nugroho B, dan Hidayah M. 2013. FaktorFaktor Yang Mempengaruhi Tingginya Cakupan Akseptor Kb Memilih Metode Kb Suntik 3 Bulan Di Desa Cupak Kecamatan Ngusikan Kabupaten Jombang. J. Metab., vol. 2, no. 2.

[5] Mustajab M. 2017. Komparasi Usahatani Padi Organik Di Desa Wijirejo Dan Kebonagung Kabupaten Bantul. Geo Edusia, vol. 2, no. 1, pp. 119.

[6] Putri AF, Raharjo ST, dan Irfan M. 2016 Pelayanan Advokasi Penghasil Pangan Skala Kecil oleh Oxfam Indonesia.

[7] Amri S, Ikhbar S, dan Mujiburrahman. 2017. Analisis Faktor-Faktor Yang Mempengaruhi Output Sektor. Seminar Nasional Kemaritiman Aceh, vol. 1, pp. 393-401.

[8] Dermoredjo SK. 2016. Analisis Kebijakan Pengembangan Padi, Jagung, dan Kedelai Di Indonesia Dalam Menghadapi Perdagangan Bebas Asean. Anal. Kebijak. Pertan., vol. 12, no. 1, pp. 51-68.

[9] Zainal IR. 2013. Evaluasi Kesesuaian Lahan Kualitatif Dan Kuantitatif Tanaman Padi Tadah Hujan (Oryza Sativa L.) Pada Lahan Kelmpok Tani Karya Subur Di Desa Pesawaran Indah Kecamatan Padang Cermin Kabupaten Pesawaran. Universitas
Lampung.

[10] Mahardika IGWD. 2016. Perbandingan Pendapatan Petani Padi yang Menggunakan Sarana Produksi Pupuk Sesuai dan Tidak Sesuai Anjuran Pemerintah (Studi Kasus Subak Gede Sukawati, Desa Sukawati, Kecamatan Sukawati, Kabupaten Gianyar). Universitas Udayana.

[11] Dona RLR. 2016. Analisis Faktor Faktor Yang Mempengaruhi Produksi Padi Di Indoneisa Tahun 2009-2013. Universitas Muhammadiyah Yogyakarta.

[12] Sucipto EI. 2013. Analisis Produksi Dan Pendapatan Usahatani Padi Sawah Di Kecamatan Purbolinggo Kabupaten Lampung Timur. Universitas Lampung.

[13] Hendrawan SA, Isnanto RR, dan Pertiwi I. 2015. Aplikasi Visualisasi 3D Pada Struktur Sistem Rangka Manusia Berbasis Android. J. Teknol. dan Sist. Komput., vol. 3, no. 4, pp. 426-435.

[14] Erdiansyah MZ dan Raharjana IK. 2016. Visualisasi Data Menggunakan Sistem Informasi Geografis untuk Potensi Bank Sampah di Surabaya. J. Inf. Syst. Eng. Bus. Intell., vol. 2, no. 1, pp. 40-49.

[15] Hakam DPE dan Atletiko FJ. 2018. Rancang Bangun Visualisasi Usulan Penduduk Kota Surabaya Pada Situs Monvis-Musrenbang Surabaya. J. Tek. ITS, vol. 7, no. 1, p. 118.

[16] Siswanto IA. 2016. Aplikasi Visualisasi Data Mahasiswa dan Dosen Dengan Memanfaatkan Hightchart. J. Manaj. Informasi, vol. 5, no. 2, pp. 93-98.

[17] Kamus Besar Bahasa Indonesia. .

[18] Hidayat W. 2014. Visualisasi Data Jumlah Penduduk Dalam Bentuk Kartogram (Studi Kasus Di Daerah Istimewa Yogyakarta). Universitas Gajah Mada.

[19] Microsoft, Power BI | Interactive Data Visualization BI Tools. https://powerbi. microsoft.com/en-us/. Diakses pada tanggal 06 Juni 2018.

[20] Microsoft. Tips and Tricks for Power BI Map visualizations. https://docs.microsoft.com/enus/power-bi/power-bi-map-tips-and-tricks. Diakses pada tanggal 07 Juni 2018.

[21] Listiyoko L, Ardi RA, Maksum A, S. Informasi, dan M. T. Informatika. Implementasi Live Dashboard Dalam Pengembangan Business Intelligence Pada E-Learning STMIK Muhammadiyah Banten. Seminar Nasional Teknologi Informasi dan Multimedia, pp. 145-150.

[22] Roihan A dan Maksum A. 2018. Konsep Data Mart Dalam Implementasi Sistem Job Fair Menggunakan Metode Online Analytical Processing Pada Dinas Tenaga Kerja. Seminar Nasional Teknologi Informasi dan Multimedia, pp. 61-66. 